\title{
Is increasing the dose of Entecavir effective in partial virological responders?
}

This article was published in the following Dove Press journal:

Drug Design, Development and Therapy

29 May 2014

Number of times this article has been viewed

\author{
Ayse Erturk' \\ Remzi Adnan Akdogan ${ }^{2}$ \\ Emine Parlak ${ }^{3}$ \\ Erkan Cure ${ }^{2}$ \\ Medine Cumhur Cure ${ }^{4}$ \\ Cinar Ozturk' \\ 'Department of Infectious Diseases, \\ 2Department of Gastroenterology, \\ School of Medicine, Recep \\ Tayyip Erdoğan University, Rize, \\ Turkey; ${ }^{3}$ Department of Infectious \\ Diseases, School of Medicine, \\ Ataturk University, Erzurum, Turkey; \\ ${ }^{4}$ Department of Biochemistry, School \\ of Medicine, Recep Tayyip Erdoğan \\ University, Rize, Turkey
}

Correspondence: Ayse Erturk

Department of Infectious Diseases,

School of Medicine, Recep Tayyip Erdoğan

University, Rize, Turkey

Tel +9004642130492

Email ayseace25@hotmail.com
Objective: To analyze the effect of increasing Entecavir (ETV) dosage in patients with chronic hepatitis B (CHB) who partially responded to ETV after 1 year.

Methods: Twenty-three hepatitis B e antigen ( $\mathrm{HBeAg}$ )-positive and $36 \mathrm{HBeAg-negative}$ patients with CHB were treated with ETV $0.5 \mathrm{mg}$ daily. After 1 year of the treatment, those with detectable hepatitis B virus (HBV-DNA) were randomized to either ETV $0.5 \mathrm{mg}$ or $1 \mathrm{mg}$ daily. The resistance to ETV was excluded. Both groups received ETV for 3 years. The groups were compared in aspects of undetectable DNA.

Results: Group 1 was given $0.5 \mathrm{mg}$ ETV and included 32 patients (20 HBeAg-negative and $12 \mathrm{HBeAg}$-positive). Group 2 was given $1 \mathrm{mg}$ ETV and consisted of 27 patients (16 HBeAgnegative and eleven HBeAg-positive). Group 2 had more effective suppression of HBV-DNA while both groups had comparable rates of $\mathrm{HBeAg} \operatorname{loss}(58 \%$ and $63 \%$ for group 1 and group 2, respectively) and alanine transaminase (ALT) normalization at the end of 4 years.

Conclusion: Increasing ETV dose from $0.5 \mathrm{mg}$ to $1 \mathrm{mg}$ after 1 year of ETV treatment may provide an effective suppression of viral replication.

Keywords: chronic hepatitis B, treatment, entecavir, treatment, patient monitoring

\section{Introduction}

Chronic hepatitis B (CHB) virus infection is still an important health issue in the world. The aim of hepatitis B treatment is to improve the quality of life and survival via preventing the disease progression to cirrhosis, decompensated cirrhosis, end-term liver failure, hepatocellular carcinoma, and death. This aim can only be achieved by a sustainable way of suppressing hepatitis B virus (HBV) replication. The ultimate goal of the treatment is hepatitis B surface antigen (HBsAg) loss. However, this can be rarely achieved by recent anti-HBV agents. The more realistic aim is to stimulate viral remission by suppressing HBV-DNA permanently.

Entecavir (ETV), an oral deoxyguanosine nucleoside analogue (NA), is generally well tolerated in patients with CHB who have decompensated liver disease. Some studies have demonstrated ETV to be as safe as a monotherapy for first-step treatment. ${ }^{1-3}$ Additionally, several studies have shown this high-genetic barrier medication to not cause any serious side effects that require discontinuation of the drug. ${ }^{4-6}$ Adult ETV dose is $0.5 \mathrm{mg}$ per day for medication-naive persons and $1 \mathrm{mg}$ per day for medicationresistant patients.

It has been argued that ETV shows similar in vitro sensitivity in all HBV genotypes (A, B, C, D, F, and G). ${ }^{7}$ In patients with nucleoside-naïve hepatitis B e antigen (HBeAg)-negative $\mathrm{CHB}$, the genotypic resistance rate was reported to be as low as 
$1.2 \%$ after a 5 -year period of treatment. However, virological breakthrough (which means after a virological response [VR] to treatment there is an increase of HBV-DNA levels at 10 times $[>1 \log$ ]; or an increase HBV-DNA positivite after being polymerase chain reaction [PCR] negative assessment) has been found to be as $0.8 \%$ ratio. The virological remission rates in which patients with $\mathrm{HBeAg-positive}$ and $\mathrm{HBeAg}$-negative $\mathrm{CHB}$ had compliance to the treatment ( $>90 \%$ and $>95 \%$, respectively) can be protected by continuing ETV treatment after $\geq 3$ years. ${ }^{1,5,8,9}$ During ETV treatment, viral suppression cannot be achieved in a group of patients. After 48 weeks of treatment, the management of those with any detectable HBV-DNA is not clearly known. After exclusion of ETV resistance, the drug can be continued or a modification of the treatment can be considered.

The aim of this study was to evaluate the effects of increasing ETV dosage from $0.5 \mathrm{mg}$ to $1 \mathrm{mg}$ in CHB patients without resistance but who still had detectable HBV-DNA.

\section{Material and methods Patients}

This study was conducted in Recep Tayyip Erdogan University, School of Medicine, Departments of Infectious Diseases and Gastroenterology, Rize, Turkey and Ataturk University, Department of Infectious Diseases, Erzurum, Turkey with 59 patients who had CHB-related liver disease. The study was approved by local ethics committees and informed consent was obtained from each participant (approval date: 2013/18).

Patients with other concomitant causes for chronic liver disease (hepatitis $\mathrm{C}$ virus infection, alcohol consumption, autoimmunity) or with human immunodeficiency virus infection were excluded from this study. Seven patients who were not compatible with treatment-control were excluded. Twenty-three patients had a positive HBeAg while 36 patients had a negative HBeAg. Male sex was $69 \%$ of patients. The mean age was $44.06 \pm 13.19$ years. The mean weight was $75.5 \pm 8.98 \mathrm{~kg}$. All patients were given ETV $0.5 \mathrm{mg}$ daily. At the beginning of the treatment, alanine transaminase (ALT), HBV-DNA, and HBeAg levels were monitored at a minimum of 24-week intervals. Patients who showed a partial virological response at the end of the 12 th week were identified by an increase in their liver enzymes and a minimal activation of HBV-DNA levels, but there was no resistance to ETV at the end of the 48 th week.

Patients were subdivided into two groups and treated as follows: ETV treatment was continued at $1 \mathrm{mg}$ per day (patients who had previously received treatment were given an antiviral therapeutic dose) in 27 of the 59 patients and results collected over the 4 years were evaluated.

\section{Laboratory measurements}

ALT was analyzed using an Olympus AU 600 autoanalyzer (Olympus Corporation, Tokyo, Japan) using Olympus kits. $\mathrm{HBsAg}$, anti-HBs (hepatitis B surface antibody), HBeAg, and anti-Hbe (hepatitis B 'e' Antigen antibody) were determined with the enzyme linked immunosorbent assay method using the Architect i1000 (Abbott Laboratories, Abbott Park, IL, USA).

HBV-DNA was measured by PCR using a CobasTaqman 48 analyzer (F Hoffmann-La Roche Ltd, Basel, Switzerland) and the results were reported as $1 \mathrm{IU} / \mathrm{mL}=5.82$ copies $/ \mathrm{mL}$. Lower limit of quantification was 35 copies $/ \mathrm{mL}$ and a linear range of upper detection limit was $6.4 \times 10^{9} \mathrm{copies} / \mathrm{mL}$. For results exceeding the upper detection limit, HBV-DNA levels were remeasured after a 100,000-fold dilution. Primary nonresponse was defined by serum HBV-DNA reduction of less than $1 \log$ copies/mL at the 12th week or $2 \log$ copies $/ \mathrm{mL}$ at the 24th week from baseline. Partial VR (PVR) is defined as a decrease of $\geq 1 \log \mathrm{IU} / \mathrm{mL}$. Virologic breakthrough was defined by either an increase of serum HBV-DNA by at least $1 \log$ copy/mL.

\section{Statistical analysis}

Results are reported as mean \pm standard deviation. Data analyses were performed using the statistical software SPSS for Windows (version 13.1; IBM Corporation, Armonk, NY, USA). Kolmogorov-Smirnov tests were applied to all data to determine normal and nonnormal data distributions. Nonparametric tests were used to compare the data of some parameters that showed nonnormal distributions beside the sample size being low. A Wilcoxon test was performed to analyze the laboratory tests of baseline and treatment weeks. Mann-Whitney $U$ test was used to compare the patients taking dose titration of 0.5 and $1 \mathrm{mg}$ ETV. The comparison of VR levels according to weeks was analyzed by chi-square test. $P<0.05$ was determined as statistically significant.

\section{Results}

Serum HBV-DNA and ALT levels of the patients at baseline and at weeks 12, 24, and 48, and at intervals of 24 after the 96 weeks of the ETV treatments (group 1 and 2), are shown in Table 1.

Antiviral-naïve patients with $\mathrm{CHB}$ received initial therapy as ETV $0.5 \mathrm{mg}, 23$ patients whose $\mathrm{HBeAg}$ were positive and 
Table I The change in ALT and HBV-DNA levels in regard to treatment periods

\begin{tabular}{|c|c|c|}
\hline Time span & ALT (U/L) & $\begin{array}{l}\text { HBV-DNA } \log _{10} \\
\text { copies/mL }\end{array}$ \\
\hline Baseline & $|76.32 \pm 277.8|$ & $9.26 \pm 9.47$ \\
\hline I2th week & $70.17 \pm 69.89^{a}$ & $5.73 \pm 6.17^{\mathrm{a}}$ \\
\hline 24th week & $44.54 \pm 24.68^{\mathrm{a}, \#}$ & $4.32 \pm 4.73^{\mathrm{a}, \alpha}$ \\
\hline 48th week & $35.39 \pm \mid 4.00^{\mathrm{a}, \beta}$ & $4.34 \pm 4.75^{\mathrm{a}, \alpha}$ \\
\hline 72nd week & $41.03 \pm 16.6 I^{\mathrm{a}}$ & $4.17 \pm 4.28^{\mathrm{a}, \alpha}$ \\
\hline 96th week & $38.22 \pm 15.72^{\mathrm{a}}$ & $3.16 \pm 3.48^{a, \#, E, x, \neq, \neq}$ \\
\hline I44th week & $34.68 \pm \mid$ | 3.59 $9^{\mathrm{a}, \mathrm{E}, \mathrm{x}, \approx}$ & $2.47 \pm 3.00^{\mathrm{a}, \#, \pm, \mathrm{q}, \mathrm{\phi}, \mathrm{\phi}, \mathrm{M}}$ \\
\hline I68th week & $35.25 \pm \mid 4.14^{\mathrm{a}, \mathrm{E}, \mathrm{x}, \mathrm{z}}$ & $2.63 \pm 2.77^{\mathrm{a}, \#, \mathrm{,}, \mathrm{T}, \mathrm{\phi}, \mathrm{M}}$ \\
\hline 192nd week & $33.3 \mathrm{I} \pm 25.65^{\mathrm{a}, \mathrm{a}, \mathrm{T}, \mathrm{\phi}, \mathrm{M}}$ & $3.04 \pm\left. 2.7\right|^{a, \#, E, E, x, Z, U}$ \\
\hline
\end{tabular}

Notes: Data presented as mean \pm deviation. Wilcoxon test: ${ }^{a} P<0.00$ I versus baseline value. ${ }^{\#} P<0.00 \mathrm{I}, \alpha P<0.05$ versus 12 th week, ${ }^{\alpha} P<0.00 \mathrm{I},{ }^{\beta} P<0.05$ versus 24th week, ${ }^{\top} P<0.00$ I, ${ }^{\times P}<0.05$ versus 48 th week, ${ }^{\oplus} P<0.00$ I, ${ }^{¥} P<0.05$ versus 72 nd week, ${ }^{\neq} P<0.00$ I, ${ }^{M} P<0.05$ versus 96 th week, ${ }^{Z} P<0.05$ versus 144 th week, ${ }^{\cup} P<0.05$ versus 192nd week.

Abbreviations: ALT, alanine transaminase; HBV, hepatitis $B$ virus.

36 of patients with negative $\mathrm{HBeAg}$ were $\mathrm{HBeAg}$-positive and $\mathrm{HBeAg}$-negative. The mean reduction in serum HBVDNA level at the 12 th week was $3.52 \pm 3.33 \log _{10}$ copies $/ \mathrm{mL}$ and at the 24th week was $4.93 \pm 4.74 \log _{10}$ copies $/ \mathrm{mL}$ in total. The decrease in ALT and HBV-DNA levels at the 12th week was statistically significant compared to the rest of the weeks $(P<0.01$, see Table 1). Some patients were observed to have a minimal increase in their HBV-DNA levels at the 48th week $\left(0.02 \pm 0.02 \log _{10}\right.$ copies $/ \mathrm{mL}$ compared to the 24 thweek). This was followed by an increase in ALT levels $(5.64 \pm 10.68 \mathrm{U} / \mathrm{L}$ at the 72 nd week compared to the 48th week). At this stage, the treatment of 27 patients (45.7\%) was continued with ETV $1 \mathrm{mg}$ daily. Thirty-two patients $(54.3 \%)$ continued to receive $0.5 \mathrm{mg}$ daily. The titration of doses according to weeks is shown in Figure 1. The results of this study included the analysis of 4 years of treatment.

The mean age and weight of each of the two groups were: group $1(\mathrm{n}=32) 43.56 \pm 13.40$ years, $75.11 \pm 8.99 \mathrm{~kg}$; and

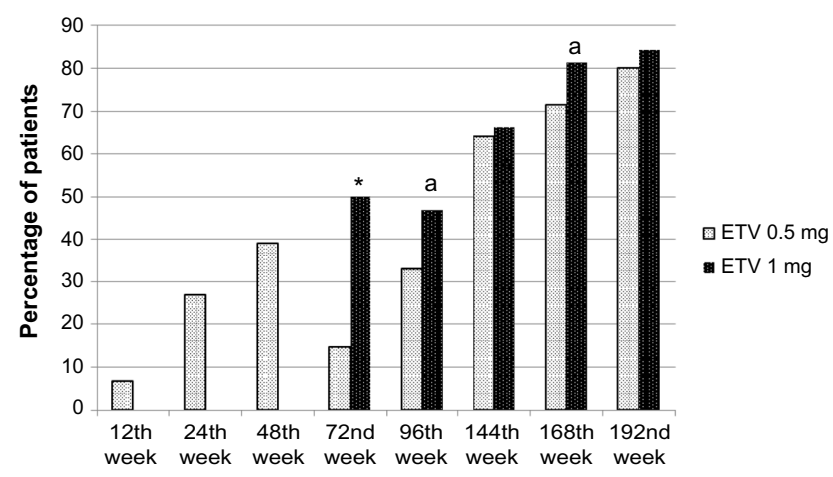

Figure I Viral responses of the two groups as percentages according to weeks. Notes: $* P<0.001 ;{ }^{a}<<0.05$. The treatment success was $84.7 \%$ of total HBV-DNA negativity and at the end of the 192nd week it was $15.3 \%$ of PVR.

Abbreviations: ETV, Entecavir; HBV, hepatitis B virus; PVR, partial virologic response. group $2(\mathrm{n}=27) 44.56 \pm 12.98$ years, $75.97 \pm 8.97 \mathrm{~kg}$. There was no statistically significant difference between the values for group 1 and group 2 of baseline HBV-DNA $\log _{10}$ copies $/ \mathrm{mL}$ (9.34 \pm 9.54 and 9.17 \pm 9.40 , respectively) and ALT U/L (195.26 \pm 368.51 and $160.35 \pm 173.01$, respectively).

In group 2, treated with a dose of $1 \mathrm{mg}$ once a day, at the end of the 1st year, there was a significant reduction in HBVDNA levels at the 72nd, 96th, and 192nd week compared to group $1(P<0.01)$. It was also significant at the 144th and 168th week $(P<0.05$ level). Biochemical response of ALT levels was not significant (Table 2). HBV-DNA and ALT changes over the follow-up period are summarized in Table 2.

\section{Discussion}

In this study, HBV-DNA levels were found to be decreased (6.22 $\pm 6.76 \mathrm{log}$ decline) at the end of the 192nd week compared to the baseline, and long term ETV therapeutic response was found to be significant when considering the reductions, which were determined at the 12th and 24th week. When considering VR ratio as $100 \%$, it was found to be $15.3 \%$ of PVR and $84.7 \%$ of the total HBV-DNA negativity. There were no resistance and also no HBsAg seroconversion. At the end of the first treatment period, in group 2 - patients who used $1 \mathrm{mg}$ daily - the reduction of HBV-DNA levels was more prominent at the end of 72nd, 96th and 192nd week compared to group 1 patients. There was also another significant reduction in favor of group 2 at the end of the 144th and 168th week. However, biochemical response of ALT was not significantly different. Patients with CHB who were nonresponsive to $0.5 \mathrm{mg}$ of ETV had nearly complete VR after being given $1 \mathrm{mg}$ of the drug. A broad population study conducted on CHB patients by Zoutendijk et al has reported $81 \%$ of VR at the end of 3 years of treatment. ${ }^{10}$ They reported that the probability to acquire a VR with ETV has not been affected by the severity of liver disease. VR obtained from ETV has been found to be correlated with lower progress of the disease (hepatocellular carcinoma, liver decompensation, death) even in patients with cirrhosis. ${ }^{10-12}$ In another study with a broader population (Virgil study ${ }^{1}$ ), CHB patients have been reported to have $76 \%-96 \%$ VR after 4 years of ETV treatment of $0.5 \mathrm{mg}$ daily dose. ${ }^{1}$

In our study, some patients had minimal increase in HBVDNA levels $\left(0.02 \pm 0.02 \log _{10}\right.$ copies $\left./ \mathrm{mL}\right)$ at the 48th week compared to the 24th week. This was followed by an increase in ALT levels (the mean increase of $5.64 \pm 10.68 \mathrm{U} / \mathrm{L}$ ) at the $72 \mathrm{nd}$ week compared to the 48th week. Despite regular follow-up of the participants, the treatment compliance was not enough. 
Table 2 Sociodemographics and laboratory measurements of the two patients groups demonstrating their ALT and HBV-DNA changes over the treatment period

\begin{tabular}{|c|c|c|c|c|}
\hline & Group I $(n=32)$ & & Group $2(n=27)$ & \\
\hline Age (years) & $43.56 \pm 13.40$ & & $44.56 \pm 12.98$ & \\
\hline Weight (kg) & $75.11 \pm 8.99$ & & $75.97 \pm 8.97$ & \\
\hline Time span & ALT & HBV-DNA & ALT & HBV-DNA \\
\hline Baseline* & $195.2 \pm 368.5$ & $9.34 \pm 9.54$ & $160.3 \pm 173.0$ & $9.17 \pm 9.40$ \\
\hline I2th week ${ }^{*, R}$ & $66.6 \pm 48.9^{\mathrm{a}}$ & $5.82 \pm 6.05^{a}$ & $73.1 \pm 84.3^{\mathrm{a}}$ & $5.64 \pm 6.23^{\mathrm{a}}$ \\
\hline 24th week ${ }^{*, \mathrm{R}}$ & $46.3 \pm 27 . I^{\mathrm{a}, \#}$ & $4.64 \pm 5.06^{\mathrm{a} \text {,\# }}$ & $43.0 \pm 22.7^{\mathrm{a}, \#}$ & $4.00 \pm 4.40^{\mathrm{a}, \#}$ \\
\hline 48th week ${ }^{*, R}$ & $36.6 \pm 12.2^{\mathrm{a}, \#}$ & $4.37 \pm 4.6 \mathrm{I}^{\mathrm{a}, \mathrm{A}}$ & $34.3 \pm 15.4^{4, \#, \beta}$ & $4.23 \pm 4.90^{\mathrm{a}, \#}$ \\
\hline 72nd week ${ }^{*, F}$ & $44.2 \pm 17.3^{\mathrm{a}, \alpha, \pi}$ & $4.48 \pm 4.90^{\mathrm{a}, \#}$ & $38.3 \pm 15.7^{\mathrm{a}, \#}$ & $3.25 \pm 3.67^{\mathrm{a}, \#, \beta}$ \\
\hline 96th week ${ }^{*, R}$ & $38.8 \pm 14 .\left.\right|^{a, \#, *}$ & $3.38 \pm 3.62^{\mathrm{a}, \#, E, \mathrm{E}, \mathrm{x}, \approx}$ & $37.7 \pm 17.1^{a, \#}$ & $2.95 \pm 3.35^{\mathrm{a}, \#, \beta, \mathrm{x}}$ \\
\hline 144th week ${ }^{*, R}$ & $34.5 \pm 11.9^{\mathrm{a}, \#, \neq, \mathrm{M}}$ & $2.7 \mathrm{I} \pm 3.29^{\mathrm{a}, \#, \mathrm{E}, \mathrm{T}, \neq, \mathrm{M}}$ & $34.8 \pm 15.0^{a, \#, \beta, \#,, M}$ & $2.24 \pm 2.62^{a, \#, \beta, x, \neq, \ldots, M}$ \\
\hline I68th week ${ }^{*, R}$ & $37.5 \pm 15.2^{\mathrm{a}, \#, \#}$ & $2.70 \pm 3.32^{\mathrm{a}, \#, \beta, \beta, \mathrm{x}, \mp}$ & $33.3 \pm 13.0^{a, \#, \beta, \beta, \phi, \phi M}$ & $2.56 \pm 2.23^{a, \#, \beta, x, M}$ \\
\hline 192nd week*,F & $39.4 \pm 35 .\left.\right|^{a, \#, \beta, \#, M}$ & $3.68 \pm 3.29^{a, \#, \beta, x, \neq, \neq, M}$ & 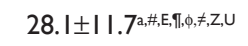 & $2.40 \pm 2.13^{\mathrm{a}, \#, \beta, x, \neq}$ \\
\hline
\end{tabular}

Notes: Mann-Whitney $U$ test: $* A L T$ was not significant in group I versus group 2 . HBV-DNA had: ${ }^{F}<0.00 I$; ${ }^{R}$ not significant in group I versus group 2 . Wilcoxon test:

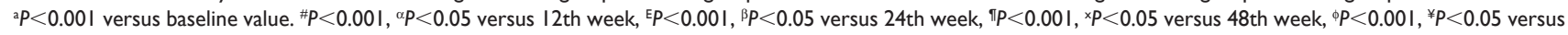
72nd week, ${ }^{\neq} P<0.001,{ }^{M} p<0.05$ versus 96 th week, ${ }^{2} p<0.05$ versus 144 th week, ${ }^{u} p<0.05$ versus 192nd week.

Abbreviations: ALT, alanine transaminase; HBV, hepatitis B virus.

Recurrent viremia or increased ALT were detected while treatment was continued without a break at the end of the 48th week. ${ }^{13}$ However, this result has not been interpreted as virological breakthrough because it was less than $1 \log _{10} \mathrm{IU} / \mathrm{mL}$. This result justified that the treatment should be continued. The treatment was continued as there was no genotypic resistance detected in the patients. ${ }^{1,13}$ After this stage, the resistance test results were found to be negative. At this stage, the treatment of 27 patients (45.7\%) was continued as ETV $1 \mathrm{mg}$ daily and 32 patients (54.3\%) continued to receive $0.5 \mathrm{mg}$ per day. In this study, we compared a group receiving $1 \mathrm{mg}$ ETV and a group treated with $0.5 \mathrm{mg}$. HBV-DNA was observed to be negative in the majority of patients. There was a sustained viral suppression in the 192nd week in patients receiving ETV $1 \mathrm{mg}$ daily. Our study had a longer duration of treatment (4 years) compared to previous studies which were followed at weeks 48, 96 and 144, respectively. In a previous study, $40 \mathrm{HBeAg}-$ positive treatment-naïve $\mathrm{CHB}$ patients were treated with ETV $1.0 \mathrm{mg}$ and compared with a control group receiving $0.5 \mathrm{mg}$ daily during a period of 5 years. The results of the 24th and 48th week were evaluated. There were no significant differences in the proportion of patients with complete viral suppression treated with ETV $0.5 \mathrm{mg}$ daily or the higher daily dose of 1.0 mg. ${ }^{14}$ Our study lasted for 192 weeks. At the end of this period, more patients had statistically significant virological response (VR) after receiving $1 \mathrm{mg}$ of ETV.

Moreover, there was not any adverse event stemming from ETV and the applied treatment was safe for the patients. ${ }^{15}$ Studies have reported ETV to be a safe medication; it has not affected renal functions, and has not caused lactic acidosis. Side effects were mostly reported in patients who have severe hepatic failure with decompensated liver disease. ${ }^{1-3,16}$ According to the European Association for the Study of the Liver, ALT normalization ratio was $68 \%$ and anti-HBe seroconversion ratio was $21 \%$ for both ETV and tenofovir treatments. The ratio of HBsAg loss was $3 \%$ of the patients treated with tenofovir and 2\% after 1 year of treatment. ${ }^{1,10}$ Anti-HBe seroconversion rates increase with continuing nucleoside analogue treatment in HBeAg-positive CHB. ${ }^{8,17,18}$ However, if the resistance occurs, it affects seroconversion..$^{19,20}$

At the beginning of the current study, 24 patients (40.6\%) had a positive $\mathrm{HBeAg}$ and 22 patients (37.2\%) had a positive anti-Hbe. At the end of the 4 years, $\mathrm{HBeAg}$ positivity was determined in 12 patients $(20.3 \%), \mathrm{HBeAg}$ clearance was detected at a ratio of $50 \%$, and anti-HBe positivity was found in 23 patients $(54.2 \%)$ which was an increase of $17 \%$. Dose modification was not found to be significant on clearances between the groups (58.2\% for group 1 and $63 \%$ for group 2). $\mathrm{HBeAg}$-negative $\mathrm{CHB}$ is the major variant of the disease worldwide. It has been revealed that VR (negativity of HBV-DNA: $<60-80 \mathrm{IU} / \mathrm{mL}$ ) to the ETV ( $0.5 \mathrm{mg}$ per day) and tenofovir (245 mg per day) treatments at the end of the 12 th month (48th or 52 nd week) was at a ratio of $90 \%$ and $93 \%$, respectively. Likewise, ALT normalization ratios were $78 \%$ and $76 \%$, respectively. ${ }^{1}$ Previous studies have shown that a 1-year treatment period is highly likely to be accompanied with antiviral resistance due to insufficient HBVDNA suppression. ETV resistance was found to be rare in nucleoside-/nucleotide-naïve $\mathrm{HBe} A g$-positive and -negative patients after 96 weeks of treatment. Additionally genotypic resistance and cumulative probability of viral breakthrough was found to be $1 \%$ and $<1 \%$ after a 5 year-treatment 
period, respectively. ${ }^{1,5,8,11,21}$ None of the current study patients with CHB lost HBsAg (neither at the end of the 48th week nor at the 96th week). However, the negative HBV-DNA $(<100$ copies $/ \mathrm{mL}$ or $17.2 \mathrm{IU} / \mathrm{mL})$ ratio was observed to be $54.3 \%$ of PVR (a decrease of $\geq 1 \log \mathrm{IU} / \mathrm{mL}$ ) and $45.7 \%$ of VR. All patients' ALT levels were normalized.

\section{Limitation of study}

The number of subjects in our study may be insufficient to represent the general population. This is only a pilot study and further studies are needed on this subject. Further and larger studies are needed with long-term follow up in terms of monitoring response for the treatment.

\section{Conclusion}

ETV treatment with a dose of $1 \mathrm{mg}$ was more effective than $0.5 \mathrm{mg}$ in reducing HBV-DNA levels without any side-effects during treatment. The success rate of the treatment increased with continuous treatment and, where necessary, with drug dose modification. The results of this study suggest ETV to have a long-term usage safety. If ETV dose needs to be increased to $1 \mathrm{mg}$, the dosage may reduce the rate of resistance to treatment.

\section{Disclosure}

The authors report no conflicts of interest in this work.

\section{References}

1. European Association for the Study of the Liver. EASL clinical practice guidelines: Management of chronic hepatitis B virus infection. $J$ Hepatol. 2012;57:167-185

2. Keating GM. Entecavir: a review of its use in the treatment of chronic hepatitis B in patients with decompensated liver disease. Drugs. 2011;71:2511-2529.

3. Zoutendijk R, Reijnders JG, Brown A, et al. Entecavir treatment for chronic hepatitis B: adaptation is not needed for the majority of naive patients with a partial virological response. Hepatology. 2011;54:443-451.

4. Khungar V, Han SH. A systematic review of side effects of nucleoside and nucleotide drugs used for treatment of chronic hepatitis B. Curr Hepatitis Rep. 2010;9:75-90.

5. Yuen MF, Seto WK, Fung J, Wong DK, Yuen JC, Lai CL. Three years of continuous Entecavir therapy in treatment-naive chronic hepatitis B patients: VIRAL suppression, viral resistance, and clinical safety. Am J Gastroenterol. 2011;106:1264-1271.
6. Yurdaydın C. Entecavir: a step forward in combating hepatitis B disease Expert Opin Pharmacother. 2008;9:3095-3109.

7. Baldick CJ, Eggers BJ, Fang J, et al. Hepatitis B virus quasispecies susceptibility to Entecavir confirms the relationship between genotypic resistance and patient virologic response. J Hepatol. 2008;48:895-902.

8. Chang TT, Lai CL, Kew Yoon S, et al. Entecavir treatment for up to 5 years in patients with hepatitis B e antigen-positive chronic hepatitis B. Hepatology. 2010;51:422-430.

9. Shouval D, Lai CL, Chang TT, et al. Relapse of hepatitis B in HBeAgnegative chronic hepatitis B patients who discontinued successful Entecavir treatment: the case for continuous antiviral therapy. J Hepatol. 2009;50:289-295.

10. Zoutendijk R, Reijnders JG, Zoulim F, et al. Virological response to Entecavir is associated with a better clinical outcome in chronic hepatitis B patients with cirrhosis. Gut. 2013;62:760-765.

11. Hadziyannis SJ, Tassopoulos NC, Heathcote EJ, et al. Long-term therapy with adefovir dipivoxil for $\mathrm{HBeAg}$-negative chronic hepatitis B. N Engl J Med. 2005;352:2673-2681.

12. Santantonio T, Mazzola M, Iacovazzi T, Miglietta A, Guastadisegni A, Pastore G. Long-term follow-up of patients with anti-HBe/HBV DNApositive chronic hepatitis B treated for 12 months with lamivudine. J Hepatol. 2000;32:300-306.

13. Pol S, Lampertico P. First-line treatment of chronic hepatitis B with Entecavir or tenofovir in 'real-life' settings: from clinical trials to clinical practice. J Viral Hepat. 2012;19:377-386.

14. Ha NB, Ha NB, Chaung KT, et al. Similar response to Entecavir 0.5 and $1.0 \mathrm{mg}$ in treatment-naïve chronic hepatitis B patients: a case-control study. Dig Dis Sci. 2014;59(1):168-173.

15. Chang TT, Gish RG, Hadziyannis SJ, et al. A dose-ranging study of the efficacy and tolerability of Entecavir in lamivudine-refractory chronic hepatitis B patients. Gastroenterology. 2005;129:1198-1209.

16. Tenney DJ, Rose RE, Baldick CJ, et al. Long-term monitoring shows hepatitis B virus resistance to Entecavir in nucleoside-naive patients is rare through 5 years of therapy. Hepatology. 2009;49:1503-1514.

17. Gish RG, Chang TT, Lai CL, et al. Loss of HBsAg antigen during treatment with Entecavir or lamivudine in nucleoside-naive $\mathrm{HBeAg}$-positive patients with chronic hepatitis B. J Viral Hepat. 2010;17:16-22.

18. Marcellin P, Heathcote EJ, Buti M, et al. Tenofovir disoproxil fumarate versus adefovir dipivoxil for chronic hepatitis B. $N$ Engl $J$ Med. 2008;359:2442-2455.

19. Heathcote EJ, Marcellin P, Buti M, et al. Three-year efficacy and safety of tenofovir disoproxilfumarate treatment for chronic hepatitis B. Gastroenterology. 2011;140:132-143.

20. Marcellin P, Buti M, Gane EJ, et al. Five years of treatment with tenofovir $D F(T D F)$ for chronic hepatitis $B(C H B)$ infection is associated with sustained viral suppression and significant regression of histological fibrosis and cirrhosis: Proceedings of the 62nd Annual Meeting of the American Association for the Study of Liver Diseases, San Fransisco, CA, USA, 6-9 November 2011. Available from: http://www.natap. org/2011/AASLD/AASLD_47.htm. Accessed April 30, 2014.

21. Yuen MF, Lai CL. Treatment of chronic hepatitis B: Evolution over two decades. J Gastroenterol Hepatol. 2011;26 Suppl 1:138-143.

\section{Publish your work in this journal}

Drug Design, Development and Therapy is an international, peerreviewed open-access journal that spans the spectrum of drug design and development through to clinical applications. Clinical outcomes, patient safety, and programs for the development and effective, safe, and sustained use of medicines are a feature of the journal, which

\section{Dovepress}

has also been accepted for indexing on PubMed Central. The manuscript management system is completely online and includes a very quick and fair peer-review system, which is all easy to use. Visit http://www.dovepress.com/testimonials.php to read real quotes from published authors. 